\title{
ТЕОРЕТИЧНА ЕКОАОГІЯ
}

\author{
УДК 911.2:574 \\ DOI https://doi.org/10.32846/2306-9716/2021.eco.3-36.18
}

\section{ГРАВІТАЦІЙНІ ВЗАЕМОДІЇ МЕК ААНДШАФТНИМИ РІВНЯМИ ПІВНІЧНО-ЗАХІДНОГО ПРИАЗОВ'Я TA ÏX ЕКОАОГІЧНI НАСАІДКИ}

\author{
Воровка В.П. ${ }^{1}$, Яцентюк Ю.В. ${ }^{2}$, Копилова Т.В. ${ }^{1}$ \\ ${ }^{1}$ Мелітопольський державний педагогічний університет імені Богдана Хмельницького \\ вул. Гетьманська, 20, 72319, м. Мелітополь, Запорізька область \\ geofak_mgpu@ukr.net, kopulova71@gmail.com; \\ ${ }^{2}$ Вінницький державний педагогічний університет імені Михайла Коцюбинського \\ вул. Острозького, 32, 21001, м. Вінниця \\ yatsentuky@gmail.com
}

\begin{abstract}
Розглянуто особливості взаємодії між висотними рівнями ландшафтів та акваландшафтів у межах Північно-Західного Приазов'я. 3'ясовано, що основу висотних рівнів досліджуваної території та акваторії становлять Приазовська височина, Приазовська і Причорноморська низовини. Глибинні рівні акваторії Азовського моря сформовані псевдолітораллю, сублітораллю та псевдоабісаллю. Головними процесами взаємодії між вказаними рівнями $є$ гравітаційні, переважно однобічні - 3 високих гіпсометричних рівнів на більш низькі з кінцевою ланкою накопичення у межах псевдоабісалі. Разом 3 гравітаційним рухом речовини відбуваються енергоінформаційні низхідні рухи. Зворотний вплив представлений переважно процесами переміщення повітряних мас, міграції живих організмів. У межах суходолу виділені верхній (170,0 м і вище), середній $(40,0-170,0$ м) та нижній $(0-40,0$ м) висотні рівні, а в акваторії - псевдоліторальний $(0,0 \ldots-1,0$ м), субліторальний $(-1,0 \ldots-$ 5,0 м) і псевдоабісальний $(-5,0 \ldots-10,0)$ акваландшафтні рівні. Найвища інтенсивність денудаційних і гравітаційно-міграційних процесів властива для верхнього гіпсометричного рівня. Тут висока інтенсивність гравітаційних процесів пояснюється найбільшою стрімкістю поверхні, близьким заляганням кристалічного фундаменту або вапнякових порід та малопотужним шаром четвертинних відкладів. Власне, гравітаційні процеси проявляються у межах стрімких схилів річкових долин, яружно-балкової мережі і денудаційних останців. Взаємодія між акваторіальними ландшафтними рівнями відбувається головним чином через берегові абразійно-акумуляційні процеси, з якими на морське дно надходить більша частина теригенних відкладів. Власне взаємодія між контрастними територіальними та акваторіальними ландшафтними утвореннями відбувається через лінію берега, де міграція відкладів завдяки прибою відбувається інтенсивно і характеризується диференційованим двобічним спрямуванням. При цьому формуються різнозернисті смуги відкладів, які сприяють формуванню специфічних донних та берегових біотопів, де розвиваються відмінні між собою екосистеми. Ключові слова: суходільні ландшафти, акваландшафти, ландшафтні рівні, гравітаційна взаємодія, донні відклади, Північно-Західне Приазов’я.
\end{abstract}

The gravitational interactions between the landscape levels of the North-Western Pryazovia and their ecological consequences. Vorovka V., Yatsentyuk Yu., Kopylova T.

The peculiarities of the interaction between the high-altitude levels of the landscapes and the aquatic-landscapes of the NorthWestern Pryazovia have been considered. It has been revealed that the basis of the high-altitude levels of the investigated territory is the Pryazovia Upland, the Pryazovia and Black Sea lowlands. The deep levels of the water surface of the Sea of Azov have been formed with the pseudo-littoral, sub-littoral and pseudo-abyssal. The main processes of the interaction between these levels are gravitational, mainly one-sided, directed from the upper hypsometric levels to the lower ones with the final element of the accumulation within the pseudo-abyssal. Together with the gravitational displacements of the substances, it is the downward movements of the energy and information. The reverse influence is represented mainly with the processes of the displacement of air mass, the migration of the living organisms, etc. Within the land, the upper (it is more than $170.0 \mathrm{~m}$ ), middle (it is $40.0 \ldots 170.0 \mathrm{~m}$ ) and lower (it is $0 \ldots 40.0 \mathrm{~m}$ ) high-altitude levels have been emphasized, and in the water surface, they are pseudo-littoral (it is $0.0 \ldots-1.0 \mathrm{~m}$ ), sub-littoral (it is $-1.0 \ldots$ $-5.0 \mathrm{~m}$ ) and pseudo-abyssal (it is $-5.0 \ldots-10.0$ ) aquatic landscape levels. The high intensity of the denudation and the gravitational-migration processes is typical for the upper hypsometric level. Here, the high intensity of the gravitational processes is explained with the greatest slopes of the surface, the close attitude of the crystalline foundation or the limestone rocks and the low-powered layer of Quaternary deposits, the presence of the steep slopes of the river valleys and the gulch-balka network. The interaction between the aquatorial landscape levels occurs mainly through the wave-sorting processes on the shallow seabed and the coastal processes, as a result of which the most part of the terrigenous sediments enter the seabed. The interaction between the contrasting territorial and the aquatorial landscape formations is carried out across the coastline, where the migration of the sediments under the influence of the swash is intensive and it is characterized with the differentiated two-sided direction. At the same time, the stripes of the different-grained sediments are formed, which contribute to the formation of the bottom and the coastal biotopes with the development of the different properties of the ecosystems. Key words: land landscapes, aquatic-landscapes, landscape levels, gravitational interaction, bottom sediments, North-Western Pryazovia. 
Постановка проблеми. Природне різноманіття географічного простору спричинює формування відповідного різноманіття його ландшафтної структури. Це супроводжується виникненням і розвитком екологічних зв'язків певних типів між їі складниками. Найбільш чіткими є зв'язки між різними висотними ландшафтними рівнями, які проявляються під дією різноманітних сил і факторів - гравітаційних, градієнтних, інсоляційних, речовинно-енергетичних та інших. На морському дні такі зв'язки проявляються по-іншому, оскільки гравітаційний фактор тут поступається прибійній діяльності і сортувальному впливу води на донні відклади. Крім того, ландшафти та акваландшафти також пов'язані між собою зв'язками певних типів через лінію берега. Дослідженню різноманіття таких взаємодій у межах Українського Приазов'я та виявленню їх екологічних наслідків і присвячена ця стаття.

Актуальність дослідження. Актуальність пов'язана як з фундаментальною, так і прикладною важливістю дослідження екологічних зв'язків та їх екологічних наслідків у береговій зоні моря. Формування нового адміністративно-територіального устрою місцевих громад приморського розташування вимагає розробки системи комплексного управління береговими зонами морів з метою подальшого раціонального їх використання. Для високої ефективності впровадження системи необхідно врахувати максимальне різноманіття природних зв'язків. Невиявлені зв'язки збільшують непередбачуваність наслідків планувальної діяльності у береговій зоні моря. Першим кроком до виявлення різноманіття природних зв'язків $\epsilon$ це дослідження.

Зв'язок авторського доробку із важливими науковими та практичними завданнями. 3 прикладних позицій необхідність дослідження пов'язана з необхідністю розробки системи комплексного управління береговою зоною моря, ефективність функціонування якої залежить від повноти врахування цих зв'язків та їх видів. В умовах формування i становлення місцевих громад це питання набуває особливої актуальності для приморських територій України. 3 наукових позицій дослідження є фундаментальним і охоплює сфери географічних та екологічних досліджень, які раніше досліджувалися окремо,суходіл та акваторію у межах берегової зони моря.

Аналіз останніх досліджень і публікацій. Дослідження суходільних ландшафтів у береговій смузі Приазов'я здійснювалося у різний час A.I. Ланьком, B.M. Пащенком, П.Г. Шищенком та іншими ландшафтознавцями. Берегова зона як прибійна смуга досліджувалася В.П. Зенковичем, А.А. Аксьоновим, Ю.П. Хрустальовим, В.А. Мамикіною, Ю.Д. Шуйським та іншими берегознавцями. Прибережні акваландшафти досліджувалися у різний час Д.Г. Пановим, В.П. Зенковичем, Ю.П.Хрустальовим,С.Ф.Шнюковим,Л.О.Беспаловою, О.В. Івлієвою та ін.
Останні дослідження і публікації по Азовському морю та його акваландшафтним складникам пов'язані з діяльністю Південного наукового центру РАН у складі колективу авторів на чолі 3 академіком Г.Г. Матишовим. Упродовж 2000-2010 рр. вийшла низка монографій, присвячених абіотичним (рельєф дна, батиметрія, донні відклади та їх диференціація i т.д.) і біотичним (різні групи рослин і тварин) складникам ландшафтної структури Азовського моря.

Виділення не вирішених раніше частин загальної проблеми, котрим присвячусться зазначена стаття. У дослідженні зроблена спроба об'єднати раніше різні сфери наукових ландшафтно-екологічних досліджень - суходолу та морської акваторії 3 береговою лінією через взаємодії між висотними рівнями (ярусами). Ці ландшафти досліджувалися навіть у різних класах ландшафтів. Незважаючи на це, вони між собою тісно взаємопов'язані різними типами зв'язків, які доцільно і необхідно досліджувати у їх цілісній сукупності. Результатом виявлених взаємозв'язків є екологічні наслідки, які суттєво впливають на стан і функціонування прибережної ландшафтної системи та її компонентів.

Новизна дослідження полягає в тому, що до цього ландшафтно-екологічні дослідження суходолу та морських акваторій здійснювалися окремо, навіть у різних категоріях ландшафтів. Тому і взаємозв' язки між ними виявлялися епізодично, несистемно. Натомість у цьому дослідженні зроблена спроба об’єднати суходільний і водний складники на прикладі гравітаційних зв'язків, виявити особливості їх взаємодії на основі дослідження висотних рівнів, а також виявити результат таких взаємодій.

Методологічне або загальнонаукове значення. Методологічне значення цього дослідження полягає у цілісному розгляді ландшафтів та акваландшафтів берегової зони моря - смуги прибережного суходолу, смуги берега і прибережної акваторії через процеси їх взаємодії та взаємозв'язку. Загальнонаукове значення - у формуванні загального уявлення про берегову зону моря як цілісну геосистему, яка складається $з$ ландшафтів та акваландшафтів.

Виклад основного матеріалу. Поняття парадинаміки та приморських взаємозв'язків між суходолом та акваторією нами вже неодноразово розглядалися на прикладі Приазовської парадинамічної ландшафтної системи [2]. Система таких взаємозв'язків надзвичайно широка i різноманітна - від прояву натуральних гравітаційних, біогенних, хемогенних, еолових до різноманітних антропогенних. Одним із найбільш стійких у просторі і часі видів взаємозв'язків є гравітаційні речовинно-енерго-інформаційні, зумовлені різницею висот рельєфу земної поверхні.

Цілісність ландшафтної системи ПівнічноЗахідного Приазов'я проявляється у взаємозв'язках між іiі рівнями, геоморфологічно представленими Приазовською височиною, Приазовською та Причорноморською (3 Присиваською лиман- 
Воровка В.П., Яцентюк Ю.В., ...

но-морською) низовинами. Прямий вплив проявляється головним чином у фізичних гравітаційних речовинних та енергоінформаційних низхідних рухах. Зворотний вплив - переважно у переміщенні повітряних мас, міграції живих організмів.

Основою прямих (у такому разі гравітаційних) зв'язків є гравітаційні процеси видалення, переміщення та накопичення пухких відкладів 3 високих гіпсометричних рівнів на низькі із загальною результуючою із суходолу у бік морського дна. Вони відбуваються у межах схилів стрімкістю від $2^{\circ}$, за якої зростає складник прискорення сили тяжіння, необхідної для переміщення частинок вниз по схилу. Інтенсивність схилових процесів зростає зі збільшенням абсолютної висоти та стрімкості схилу, а також суттєво залежить від типу гірських порід та їх міцності, від щільності і типу рослинного покриву.

Найвища інтенсивність денудаційних і гравітаційно-міграційних процесів у визначених межах Північно-Західного Приазов'я [6] характерна для верхнього гіпсометричного рівня, представленого Приазовською височиною, верхньою частиною iï схилу південної експозиції. Висотний рівень починається 3 висоти 170-180 м н.р.м. Висока інтенсивність гравітаційних процесів пояснюється найбільшою стрімкістю поверхні, близьким заляганням кристалічного фундаменту або вапнякових порід та малопотужним шаром четвертинних відкладів. Власне, гравітаційні процеси проявляються у межах стрімких схилів річкових долин, яружно-балкової мережі та денудаційних останців. Піщані та супіщані осипи властиві для стрімких схилів річкових долин, балок і ярів, осипи жорстви - для денудаційних схилів кристалічних останців, вапнякові розсипи - навколо виходів вапнякових порід. На морських берегах, складених піщано-глинистими відкладами, поширені зсуви.

Частіше в межах височин та їх схилів проявляється масове повільне переміщення (децерація) уламкового матеріалу та пухких відкладів, особливо у місцях близького залягання твердих гірських порід або щільних глин. У межах Приазовської височини термогенна і гідрогенна децерація проявляється у розривах дернового покриву та його поступовому сповзанню вниз по схилу. Результатом децерації є переривчасте сповзання окремих блоків поверхневого шару та формування мікросходинкового рельєфу (рис. 1).

На пологих та слабопохилих поверхнях височин і схилів на невкритих рослинністю сільськогосподарських полях у весняний період та на початку літа поширені делювіальні схили. У їх межах процеси змиву спричинені різким таненням снігу або зливовими опадами і проявляються у поверхневому змиві, перенесенні і відкладанні пухких відкладів густою мережею тонких, переплетених між собою струмків. Його результатом $є$ знесення пухкого матеріалу з поверхні схилу та його перевідкладання у підніжжі у вигляді супіщаного делювію.

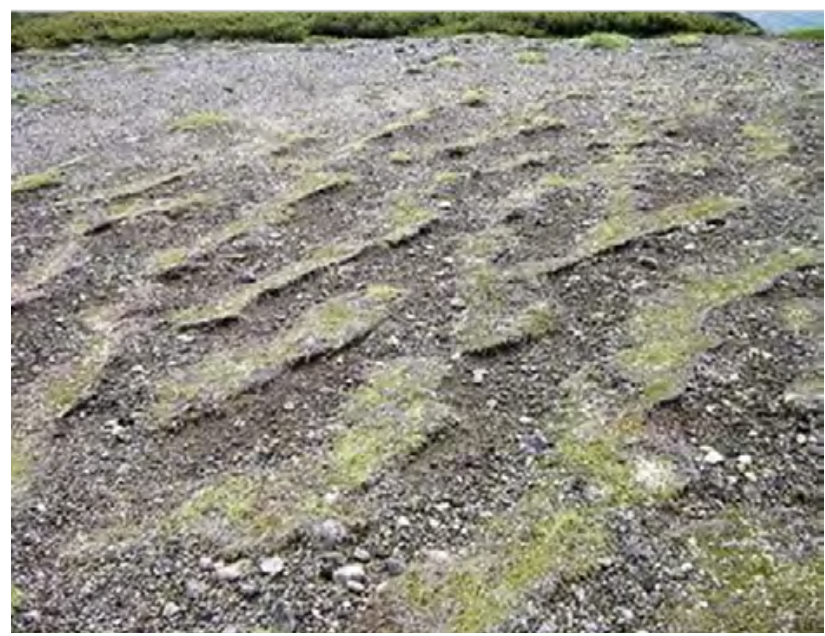

Рис. 1. Децерація (сповзання дернини) на правому схилі р. Молочна

На ділянках пологих схилів Приазовської височини розвивається площинний змив. Характерною його ознакою $є$ формування безруслових, погано виражених у рельєфі улоговин стоку (деллі), які $\epsilon$ перехідною ланкою від площинної ерозії до лінійної (рис. 2). Винесення матеріалу супроводжується формуванням у нижній частині шлейфів дрібнозему 3 найбільшою його потужністю у центрі і зменшенням до периферії. Зернистість шлейфу знижується від верхньої його частини до центральної та нижньої.

Середній гіпсометричний рівень (40-170 м. н.р.м) $\epsilon$ перехідною смугою між Приазовською височиною, іiі схилами і берегом моря. Він представлений ділянками переважно Приазовської і частково Причорноморської низовин. Цей рівень характеризується хвилястою, полого нахиленою до моря поверхнею, яка обривається берегом моря. Зменшення стрімкості схилу у його верхній частині супроводжується уповільненням міграційних потоків. Середній гіпсометричний рівень виконує більшою мірою транзитну роль і лише у верхній частині схилу - акумуляційну для речовин, що надійшли 3 верхнього гіпсометричного рівня.

Нижній гіпсометричний рівень суходолу (0-40 м н.p.м) і тектонічні опускання характерні для Причорноморської низовини. Їх майже плоска поверхня зумовлює надзвичайно слабку інтенсивність процесів міграції твердих речовин. Тут зв'язок визначається інгресією морських азовських вод у низинні ділянки суходолу з утворенням лиманів та лагун. Результатом такої взаємодії є формування системи лиманів північно-західного узбережжя Азовського моря - Сивашика, Утлюцького, Молочного, Олександрівського, Тубальського. За рахунок цього відбувається розширення морської акваторії, посилюється мікрокліматичний вплив на прилеглий суходіл, а їх мілководність разом з високою біопродуктивністю кардинально змінює характер місцеіснувань водних та навколоводних видів живих організмів. 


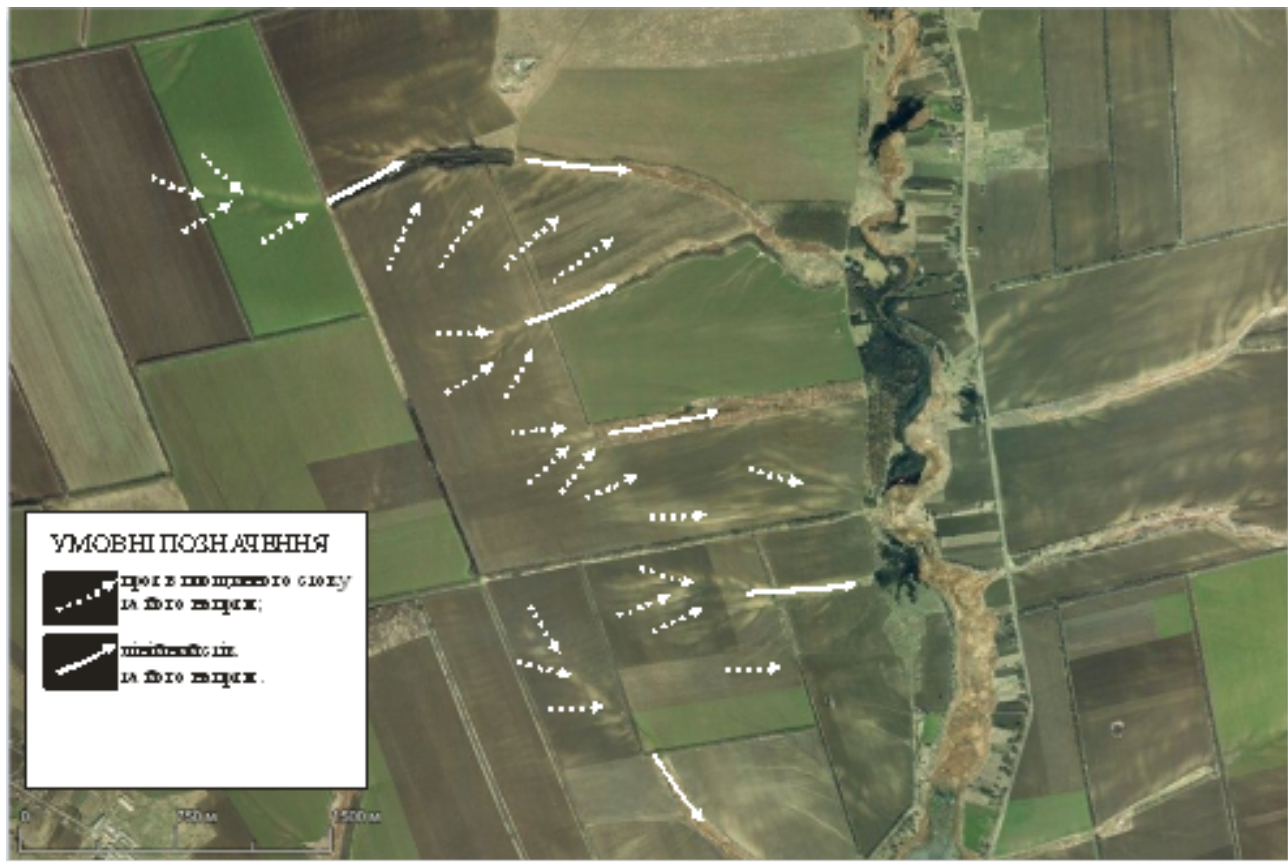

Рис. 2. Прояв площчиноӧ та лінійної ерозії на схилах Приазовської височини (фрагмент супутникового знімка)

Від'ємний гіпсометричний рівень представлений дном Азовського моря зі смугами псевдоліторалі, субліторалі та псевдоабісалі, які $є$ зоною акумуляції відкладів різних типів. Взаємодія між ними відбувається головним чином через берегові абразійно-акумуляційні процеси, з якими на морське дно надходить більша частина теригенних відкладів. Значно меншою мірою взаємодія між рівнями відбувається через річковий стік, тверда складова частина якого значною мірою знизилася внаслідок антропогенного зарегулювання. У геологічному минулому річковий стік відігравав одну з ключових ролей, сформувавши алювіальну основу акумулятивних кіс [3].

Зворотний вплив пов'язаний 3 вітроциркуляційними бризовими процесами, згінно-нагінними явищами, міграцією живих організмів по руслах i долинах річок, прибійними процесами, засоленням грунтових вод, що пов'язано з коливанням рівня Азовського моря.

Взаємодії між ландшафтними рівнями акваторіального складника Приазов'я відбуваються переважно через міграцію донних відкладів. До процесу міграції залучаються смуги псевдоліторалі глибиною 0 м...-1,0 м, субліторалі глибиною $1,0 \ldots 5,0$ м, підводні банки та псевдоабісаль 3 глибинами $5,0 \ldots 10,0$ м. Псевдо-і сублітораль $€$ транзитними смугами для надходження в акваторію з берега абіогенних відкладів (прямий зв'язок) та винесення з дна до берега біогенних (зворотний зв'язок) переважно представлених черепашками молюсків. Смуга субліторалі, розташована на більшій глибині за псевдолітораль, характеризується накопиченням переважно дрібнозернистих пісків та крупного алевриту.
Рух частинок різних розмірів у протилежних напрямках під впливом хвилеприбійної діяльності $\epsilon$ найбільш специфічним явищем серед взаємодій моря і суходолу у прибійній смузі. Цей факт для геоморфологічних наслідків взаємодії суходолу і моря відіграє вирішальне значення для формування унікальних рис прибережної смуги. Азовське море називають «морем молюсків» через його мілководність, високу температуру і динаміку вод у теплий період року та карбонатність річкового стоку, які створюють необхідні умови для високої молюскової біопродуктивності 3 домінуванням видів Cerastoderma lamarcki, Hypanis colorata, Anadara inaequivalvis, Mya arenaria, Mytilus galloprovincialis, Solen marginatus. У біомасі бентосу молюски займають домінантне положення. Їх скелетні залишки у вигляді черепашок, маючи порівняно великий об'єм, під час штормів поступово перемішуються 3 дна у бік суходолу і виносяться прибійним потоком на берег. Так формуються ділянки черепашкових пляжів та дистальні частини морських акумулятивних кіс [1]. Піщані абіогенні відклади рухаються у зворотному напрямку.

Водночас 3 поперечними у береговій смузі Азовського моря активно проявляються поздовжні, не менш контрастні, речовинно-енергетичні потоки, спрямовані уздовж лінії розподілу контрастних середовищ. Їх прояв, з одного боку, пов'язаний зі спільністю напрямів переважаючих вітрових та водного потоків уздовж берега, а 3 іншого - суттєво відрізняються у різних ділянках берегової смуги чергуванням та інтенсивністю ключових процесів абразії та акумуляції. Завдяки особливостям природ- 
Воровка В.П., Яцентюк Ю.В., ...

них умов кожної ділянки сформувалася і динамічно функціонує складна система поздовжніх та поперечних течій. У результаті цього уздовж берегової лінії відбувається чергування відмінних за походженням та інтенсивністю провідного процесу ландшафтно-геоморфологічних утворень.

Взаємодії між підводними банками та псевдоабісаллю також представлені міграцією донних відкладів. При цьому прямі зв'язки представлені потоками мушель відмерлих молюсків, більшість колоній яких розвивається саме у межах підводних банок. Завдяки зворотним зв'язкам придонні муттєві потоки забезпечують колонії молюсків органічною речовиною, яка засвоюється в результаті фільтрації. Яруси суходолу та різнорівневі донні смуги взаємодіють між собою з проявом прямих, зворотних та двосторонніх зв'язків (рис. 3).

В основному відклади добре сортовані на мілководді, а зі збільшенням глибини та віддаленням від берега сортування погіршується із закономірним зменшенням медіанного діаметру часток від піщаних (1,0-0,1 мм у межах псевдоліторалі) до алевритових (0,1-0,01 мм у межах субліторалі) та пелітових (0,01-0,001 мм у псевдоабісалі). Відбувається закономірне формування смуг різнозернистих відкладів дна

\section{ГРАВІТАЦІЙНІ ВЗАЄМОДІЇ...}

Смуга піщаних відкладів дна з вмістом піску понад $50 \%$ сформувалася вузьким шлейфом на глибинах до 6,0 м та на підводному береговому схилі акумулятивних кіс. Вона чітко виражена в межах ПівнічноЗахідного Приазов'я і пов'язана з інтенсивним хвилевим режимом. Піщано-черепашкові відклади смуги піщаних відкладів із середньо- та дрібнозернистим піском (фракція 1-0,1 мм > 70\%) та значним вмістом черепашок концентруються переважно у прибережній смузі до глибини 5-6 м. Це пов'язано з переважанням доберегового перенесення мушель 3 морського дна та активною гідрогенною диференціацією.

Піски алевритово-мулисті (1-0,1 мм - 50-70\%) поширені вузькою смугою уздовж узбережжя Арабатської стрілки, п-ова Бірючого, кіс Федотової та Обіточної з однойменними затоками. Положення смуги зумовлене переважанням відберегового перенесення теригенних піщанистих відкладів внаслідок інтенсивної гідрогенної диференціації.

Змішаний тип осадів (алевритово-мулисто-піщаний $з$ вмістом кожної фракції 30-40\%) найбільше поширений на дні Обіточної, Бердянської та Білосарайської заток, у підніжжях кіс та навколо донних пасом північної частини акваторії в межах глибин 7-9 м. Таке місцеположення та змішаний характер осадів пов'язані з поступовим затухан-

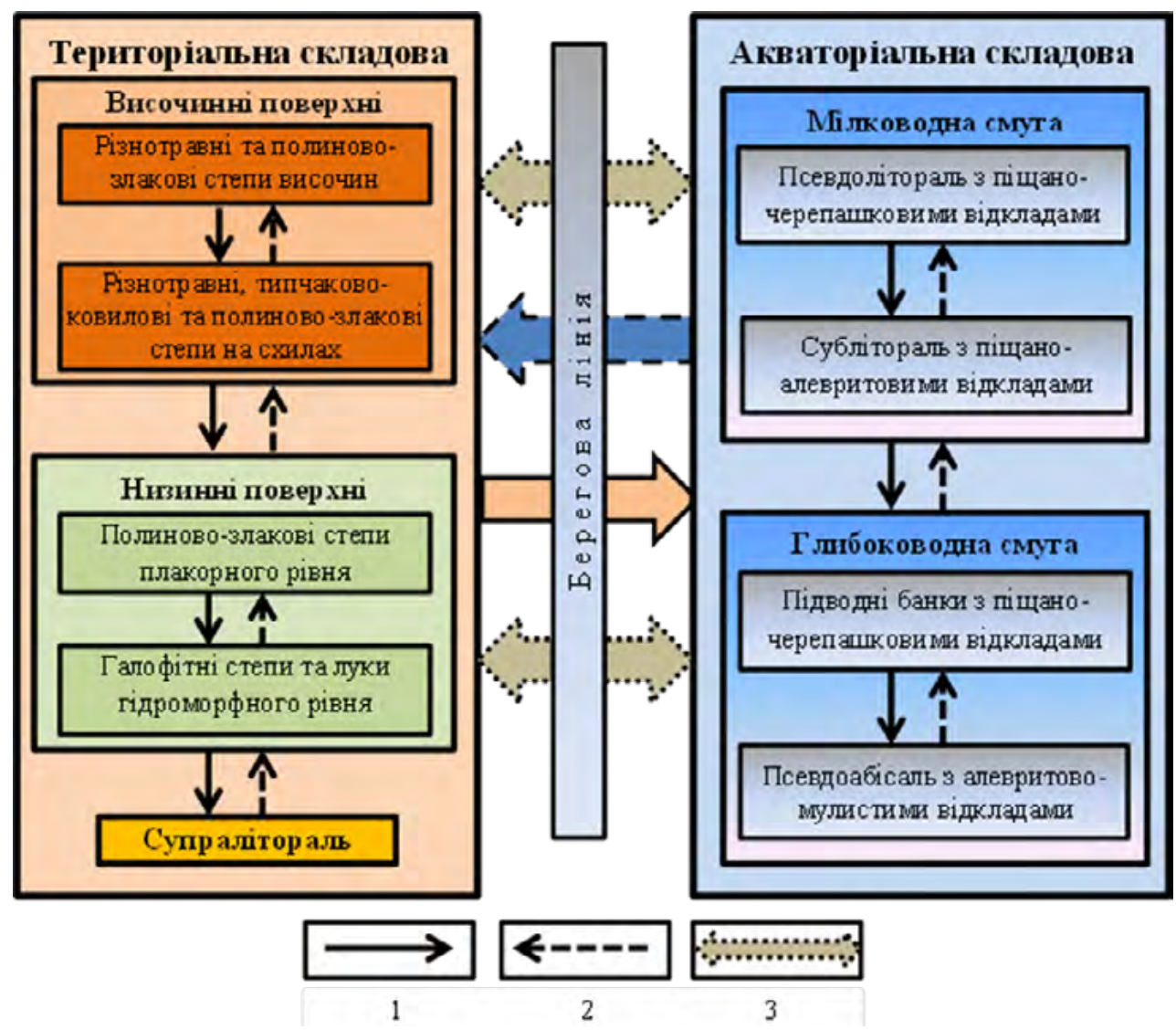

Рис. 3. Система парадинамічних зв'язків між ландшафтними рівнями акваторіальної і територіальної складових частин Північно-Західного Приазов'я. зв'язки: 1 - прямі; 2 - зворотні; 3 -двосторонні 
ням впливу хвилевих процесів на морське дно. Алевритові відклади (фракція 0,1-0,01 > 70\%) поширені переривчастою смугою уздовж північного узбережжя від північної частини Арабатської стрілки переважно на глибинах 8-9 м. Вона характеризується домінуванням процесів гідрогенної диференціації над гравітаційним осадженням завислих речовин.

Мулисто-алевритові відклади приурочені до найглибших зон прибережної акваторії з ізобатами 9-10 м. Тут гідрогенна диференціація відкладів дна низька, але ще переважає над гравітаційним осадженням. Мулисті відклади з домішкою піщано-алевритової фракції поширені в зонах зі слабким рухом придонних шарів води та врівноваженням процесів гідрогенної диференціації та гравітаційного осадження (затоки, лимани). На морському дні 3 поширенням глинистих мулів (пеліти) гідрогенна диференціація проявляється слабо і переважає гравітаційне осадження відкладів 3 водної товщі.

Характерним явищем седиментогенезу Азовського моря є змішаний тип донних відкладів. Їх відмінна риса - суміш у близьких пропорціях (від $25 \%$ до 40\%) фракцій мулу, алевриту і піску включно з детритом. Ареали донних відкладів змішаного типу тяжіють до підніжжя донних банок та до центральних понижень дна у великих затоках [5].

Посилення інтенсивності зв'язку суходолу 3 морською акваторією проявляється у збільшенні швидкості седиментогенезу: середня його швидкість упродовж новоазовського часу становить від 0,4-0,8 до 1,5-2,0 мм/рік з максимальними показниками 6 мм/рік поблизу високих берегових обривів і зон зсувів [4]. На південь від Бердянської затоки упродовж останніх 700 років швидкість накопичення осадів становила 1,5 мм/рік, а верхній 70-см шар сформувався упродовж XX ст. зі швидкістю $10 \mathrm{мм} /$ рік [5].

Головним екологічним наслідком взаємодії висотних і глибинних рівнів $є$ переміщення твердої речовини 3 верхніх на нижні гіпсометричні рівні. Тим самим відбувається поступове вирівнювання (нівелювання) земної поверхні - руйнування випуклих частин рельєфу та заповнення зруйнованим матеріалом западин рельєфу. Разом з цією речовиною відбувається міграція вниз по схилу енергії та інформації. В таких умовах сформувалися і функціонують автономні і підлеглі степові екосистеми, структура і функціонування яких враховують такі взаємодії. У межах акваландшафтів гравітаційне осідання і переміщення осадів поступається донній диференціації відкладів, що пояснюється мілководністю моря та високою інтенсивністю руху води. Наявність смуг різнозернистих відкладів сприяє формуванню специфічних донних та берегових біотопів, у межах яких розвиваються відмінні між собою екосистеми. Вони є динамічними у просторі і часі, цілком залежачи від напряму і сили вітрових хвиль.

Головні висновки. Тісний зв'язок між висотними ландшафтними рівнями суходолу та акваторії в межах Українського Приазов'я забезпечується гравітаційними потоками речовини, енергії та інформації. Однак такий зв’язок є переважно однобічним i спрямований 3 верхніх ландшафтних рівнів на нижні. Кінцевою ланкою міграції та накопичення $\epsilon$ западини морського дна, де накопичуються переважно мулисті відклади.

Одним 3 перспективних напрямів використання результатів дослідження є визначення місць встановлення штучних рифів для нересту бичкових видів риб з урахуванням прибійної динаміки та седиментаційних процесів на дні.

\section{Література}

1. Воровка В.П. Ландшафтна унікальність акумулятивних кіс Приазовської парадинамічної ландшафтної системи (на прикладі Північно-Західного Приазов'я). Вісник Чернівецького національного університету імені Юрія Федьковича. Випуск 612-613. Географія. Чернівці, 2012. С. 17-21.

2. Воровка В.П. Приазовська парадинамічна ландшафтна система : дис. ... докт. геогр. наук : 11.00.11. Київ, 2018.415 с.

3. Зенкович В.П. Берега Черного и Азовского морей. Москва : Государственное издательство географич. лит-ры. 1958.376 с.

4. Матишов Г.Г., Ковальова Г.В., Польшин В.В. Новые данные о скорости седиментации в Азовском море в позднем голоцене. Доклады АН. 2009. Т. 428. № 6. С. 820-823.

5. Экологический атлас Азовского моря / Гл. ред. акад. Г.Г. Матишов ; отв. ред. Н.И. Голубева, В.В. Сорокина. Ростовна-Дону : Изд. ЮНЦ РАН, 2011. 328 с.

6. Vorovka V., Hryshko S. Determining the boundaries of the North-Western Pryazovia region as a coastal zone for further studying and managing it. Czasopismo Geograficzne. Tom LXXXVIII. Part 1-2, Warszawa, 2017. P. 21-31. 